\title{
Secondary School Students' Predictors of Science Attitudes
}

\section{Cemal TOSUN*}

Received: 08 April 2015
Murat GENÇ ${ }^{* *}$

Accepted: 24 June 2016

\begin{abstract}
The purpose of this study is to identify the factors that affect the secondary school students' attitudes in science. This study was conducted using survey method. The sample of the study was 503 students from four different secondary schools in Bartın and Düzce. Data were obtained using the Survey of Factors Affecting Students' Science Attitudes (SFASSA) and the Survey to Determine the Degree of Importance of Categories Affecting Students' Science Attitudes (SDDICASSA). Qualitative data were subjected to a content analysis. For the analysis of the quantitative data, descriptive analysis was used. According to the results of the study, teacher is the most important category affecting the students' science attitudes
\end{abstract}

Keywords: Predictors of science attitude, science attitude, secondary school students.

\section{Introduction}

Attitude can be defined as a predisposition to respond positively or negatively towards people, places, events, and ideas (Simpson, Koballa, Oliver, \& Crawley, 1994). Whether the attitudes are positive or negative affects the learning process. It also supports the students in shaping their future lives (Seferoglu, 2004). According to Hendrickson (1997), attitude is the best predictor of a student's success.

When the impact of attitude on the success of a course is considered, it becomes evident that it is necessary to plan, organize, and implement the activities so that the students can develop more positive attitudes (Pintrich \& Schunk, 1996). Bloom (1979) addresses the importance of attitudes by stating that emotional domain behaviors have an impact on gaining the cognitive domain behaviors in science classes. It is stated that the attitudes of the students should be positive for them to be successful in science (Yesilyurt, Kurt, \& Temur, 2005; Altinok \& Acikgoz, 2006).

In general, the studies regarding science education look into the attitudes of students, who receive education at different levels, in science course (Kind, James \& Barmby, 2007; Pell \& Jarvis, 2001; Reid \& Skryabina, 2002). Some studies state that the students do not like this course much, and that their attitudes towards this course are at a low level (Dawson, 2000; Osborne, Simon \& Collins, 2003). However, some

\footnotetext{
* Assoc. Prof. Dr., Bartın University, Bartın, Turkey, ctosun@bartin.edu.tr

** Corresponding Author: Assoc. Prof. Dr., Düzce University, Düzce, Turkey, muratgenc77@gmail.com
}

\section{Citation Information}

Tosun, C. \& Genç, M. (2016). Secondary school students' predictors of science attitudes. Kuramsal Eğitimbilim Dergisi [Journal of Theoretical Educational Science], 9(4), 497-514. 
studies found that the students generally have a positive attitude towards the science course (Sen \& Koca-Ozgun, 2005; Turkmen, 2002).

Baykul (1990) puts forth that the students' attitudes change in time as a result of being affected by different causes. George (2000) states that students' attitudes in science course are affected by their parents, their peer groups, schools, and other social factors. In their literature review, Osborne et al. (2003) classify the factors affecting the students' science attitudes as; gender, personal characteristics, teacher, curriculum change, and the difficulty to perceive science.

In parallel with those classifications, particularly the teachers' impact on the attitudes of students draws attention. Studies have shown that the teachers' science attitude have a great impact on the students' attitude in science course (Bloom, 1989; Palmer, 2001). Here, the significant point is that the impact of teachers' science attitude on changing the students' attitudes is so important that it cannot be underestimated (Koballa \& Crawley, 1985; McDevitt et al., 1993; Stefanich \& Kelsey, 1989). In addition, studies have shown that the teachers' science teaching attitudes have an impact on students' understanding of science (Franz \& Enochs, 1982; Tilgner, 1990; Tosun \& Genc, 2015) and on their in-class activities (Richardson, 1996; cited in Cho, ChungAng, Kim \& Choi, 2003). It is necessary to expand those studies, identify the other factors that affect the student attitudes and identify the effect level of those factors.

The number of studies is very limited related variables as secondary school students' predictors of attitudes in science course that examined in a collected manner. There may be many factors that influence the attitudes of students in science classes but it is of great importance to determine which categories are more important than the others. The purpose of this study is to identify the factors that affect the students' science attitudes based on the perceptions of the secondary school students at different grade levels. As the second purpose, the importance degree of the categories formed by these factors on the science attitudes will be identified and the answers will be sought for the following research questions:

1. Is there any difference among the importance degree averages of science attitude predictors by gender?

2. Is there any difference among the importance degree averages of science attitude predictors by grade level?

\section{Method}

This study utilizes the survey method from amongst the non-experimental research designs, which is one of the quantitative research method (Fraenkel \& Wallen, 2009 , p. 12). The factors affecting secondary school students' science attitudes will be determined with this method in accordance with the student opinions. In addition, the student opinions will be utilized when identifying the importance degree of the categories formed by these factors. This method is used to identify the types of knowledge such as individuals' attitudes, beliefs and opinions (McMillan \& Schumacher, 2006; Fraenkel \& Wallen, 2009). 


\section{Participants}

Study sample was selected using the convenience sampling technique (Fraenkel \& Wallen, 2009). In order to find out what factors affect the secondary school students' science attitudes and which the categories of various factors are more important, the students were asked about this. A total of 126 secondary school students from different grade levels in Bartın and Düzce participated in this stage of the study. 27 of those students were at the $5^{\text {th }}$ class, 45 of them were at the $6^{\text {th }}$ class, 25 of them were at the $7^{\text {th }}$ class and 29 of them were at the $8^{\text {th }}$ class.

After being identified students' predictors of attitudes in science course, 503 secondary school students that they are studying in four different schools in Bartin and Düzce were referred for opinions. When designating the sample, the proximity of individuals to the researchers and their accessibility were taken into consideration. It can be said that those schools are mid-level schools in the light of socio-economic conditions and student profiles of Bartın and Düzce provinces. Demographic information about of the sample size are presented in Table 1.

Table 1

Demographic Information of the Sample Size

\begin{tabular}{ccccccccccc}
\hline \multicolumn{1}{c}{ Grade Level } & \multicolumn{4}{c}{ Gender } \\
\hline & $5^{\text {th }}$ & $6^{\text {th }}$ & $7^{\text {th }}$ & $8^{\text {th }}$ & Not specified & Total & Females & Males & Not specified & Total \\
\hline $\mathrm{f}$ & 63 & 184 & 139 & 112 & 5 & 503 & 245 & 255 & 3 & 503 \\
$\%$ & 12.5 & 36.6 & 27.6 & 22.3 & 1.0 & 100 & 48.7 & 50.7 & .6 & 100 \\
\hline
\end{tabular}

\section{Data Collection Tool}

Survey of Factors Affecting Students' Science Attitudes (SFASSA). A Survey of Factors Affecting Students' Science Attitudes (SFASSA) was used in order to identify the secondary school students' views regarding the factors affecting their attitudes in science course. The survey form prepared by Tosun et al. (2015) was utilized when preparing the survey form for the research. The survey was applied by the branch (science) teachers in the classroom environment under the supervision of the researchers on the appropriate class hours. In this survey, the students were asked to carry out discussions in groups and then list the most important 10 (ten) factors that affected their attitudes towards the science course according to the order of importance. The students were asked to write down the 10 factors they identified after discussing in groups in the gaps by their importance order on the survey sheet. Total of 126 secondary school students from different grade levels in Bartın and Düzce participated in this stage of the study. The views of two experts working in science education were received for the content validity of the survey. 


\section{Survey to Determine the Degree of Importance of Categories Affecting} Students' Science Attitude (SDDICASSA). After identifying the categories that affect the secondary school students' attitudes in science course, the Survey to Determine the Degree of Importance of Categories Affecting Students' Science Attitude (SDDICASSA) was used to determine the importance of these categories. This survey included the six categories (Learning-Teaching Process, Teacher, Environment-SocioCultural, Discipline, Student and School) that affected the students' science attitudes. For the sake of example of the categories in the survey: Category 1: This category includes the statements about "whether the course interesting us, entertaining course content, whether the course helps the choice of profession, duration of the course, etc." Regarding this category named as "course", they were asked to write 1 down if this category affects their attitudes in the science course on the lowest level; or to write 6 down if on the highest level and order them in comparison. By this means, they identified the importance degree of each category for their science attitudes. Appendix 1 involves each category in the survey and the statements in this category. Students evaluated the categories included in this survey according to the extent these categories affected their attitude in science course by giving one (1) to the one least affecting categories and six (6) to the most affecting categories. The views of two experts working in science education were received for the content validity of the survey. The surveys were applied by the branch (science) teachers in the classroom environment under the supervision of the researchers on the appropriate class hours.

\section{Data Analysis}

Qualitative data was subjected to a content analysis. Content analysis is accessed with the new concept and themes that can describe of the data collected (Yildirim \& Simsek, 2006, p. 228). The data obtained in the research were analyzed in five phases according to Yildirim and Simsek (2008):

These are;

I. Data were coded and entered into the Excel program.

II. Examining the codes, codes the similarities between them (relations) are included in the same category. For example, codes, such as laboratory applications, teaching methods, course materials, are grouped under the category of learning-teaching process.

III. Editing code and themes: Codes and categories are arranged to interpret the data as a whole.

IV. Codes and categories that make up the data were compared by two researchers and similarities and differences of codes and categories were examined. Comparison of the points given by two or more evaluators is considered the reliability among the evaluators (Fraenkel, Wallen, \& Hyun, 2012, p.158).

V. Findings were reviewed to make sense of the data and demonstrate some results. 
Codes derived from the unrefined data have been categorized the title of Learning-Teaching Process, Teacher, Environment-Socio-Cultural, Discipline, Student and School. Also a frequency value of each code has been removed and evaluations are made. Data obtained by SDDICASSA were analyzed using SPSS 18 package program. Descriptive analysis was used, and the mean and standard deviation values were calculated. Since the data did not exhibit a normal distribution, Mann-Whitney U test and Kruskal-Wallis test were performed.

\section{Results}

Factors affect the secondary school students' science attitudes are determined in accordance with students' opinions. Students' opinions were analyzed by content analysis. Discipline, Teacher, Environment-Socio-Cultural, Learning-Teaching Process, Student and School categories derived from the code were created.

The most important factor of 10 that affect the secondary school students' science attitudes can be listed as follows: teaching methods ( $\mathrm{f}=44)$, course materials $(\mathrm{f}=37)$, physical hardware of the school $(\mathrm{f}=26)$, whether the course is interesting $(\mathrm{f}=24)$, rules we have to obey in the class $(\mathrm{f}=20)$, laboratory applications $(\mathrm{f}=18)$, behaviors of our friends $(\mathrm{f}=17)$, grading system of the course $(\mathrm{f}=16)$, listening the course carefully $(\mathrm{f}=12)$ and teacher's physical-emotional-psychomotor behaviors $(\mathrm{f}=12)$. Other factors are presented in Table 2.

When Table 2 is examined, the distribution of the factors affecting the secondary school students' science attitudes were analyzed by categorized. Frequency distribution is as follows: Learning-Teaching Process $(\mathrm{f}=130)$, Teacher $(\mathrm{f}=61)$, Environment-SocioCultural ( $\mathrm{f}=50$ ), Discipline ( $\mathrm{f}=49)$, Student $(\mathrm{f}=28)$ and School $(\mathrm{f}=27)$. The following is the frequency distribution according to the categorization of the first 10 factors affecting secondary school students' science attitudes according to their opinions: learningteaching process $(f=4)$, environmental/socio-cultural $(f=2)$, course $(f=1)$, teacher $(f=1)$, student $(\mathrm{f}=1)$, and school $(\mathrm{f}=1)$. The study results put forth that the majority of secondary school students think that the most important factor affecting their attitudes in science course is the Learning-Teaching Process. 
Table 2

Codes and Categories Affecting the Student Attitudes in Science Course

\begin{tabular}{|c|c|c|c|c|c|}
\hline Categories & Codes & f & Categories & Codes & $\mathbf{f}$ \\
\hline \multirow{6}{*}{ Discipline } & $\begin{array}{l}\text { Whether the course is } \\
\text { interesting }\end{array}$ & 24 & \multirow{6}{*}{$\begin{array}{l}\text { Learning- } \\
\text { Teaching } \\
\text { Process }\end{array}$} & $\begin{array}{l}\text { Laboratory } \\
\text { applications }\end{array}$ & 18 \\
\hline & Course content & 5 & & Teaching methods & 44 \\
\hline & $\begin{array}{l}\text { Course shapes the choice of } \\
\text { profession }\end{array}$ & 6 & & Course materials & 37 \\
\hline & Course duration & 11 & & $\begin{array}{l}\text { Grading system of the } \\
\text { course }\end{array}$ & 16 \\
\hline & \multirow[t]{2}{*}{ Other } & 3 & & $\begin{array}{l}\text { Penalty-awards in } \\
\text { learning-teaching } \\
\text { process }\end{array}$ & 8 \\
\hline & & & & Other & 7 \\
\hline & Total & 49 & \multirow{6}{*}{ Student } & Total & 130 \\
\hline \multirow{6}{*}{ Teacher } & $\begin{array}{l}\text { Teacher's pedagogic } \\
\text { knowledge }\end{array}$ & 11 & & $\begin{array}{l}\text { Listening the course } \\
\text { carefully }\end{array}$ & 12 \\
\hline & $\begin{array}{l}\text { Teacher's physical- } \\
\text { emotional-psychomotor } \\
\text { behaviors }\end{array}$ & 12 & & Making repetitions & 3 \\
\hline & Liking the teacher & 5 & & $\begin{array}{l}\text { Studying } \\
\text { systematically }\end{array}$ & 3 \\
\hline & Other & 33 & & $\begin{array}{l}\text { Participating to the } \\
\text { course }\end{array}$ & 3 \\
\hline & & & & Other & 7 \\
\hline & Total & 61 & & Total & 28 \\
\hline \multirow{4}{*}{$\begin{array}{l}\text { Environment- } \\
\text { Socio-Cultural }\end{array}$} & $\begin{array}{l}\text { Rules we have to obey in the } \\
\text { class }\end{array}$ & 20 & \multirow[t]{3}{*}{ School } & $\begin{array}{l}\text { Physical hardware of } \\
\text { the school }\end{array}$ & 26 \\
\hline & Behaviors of our friends & 17 & & Other & 1 \\
\hline & Other & 13 & & & \\
\hline & Total & 50 & & Total & 27 \\
\hline
\end{tabular}

After the determination of secondary school students' predictors of attitudes in science course, data were collected from different and larger sample to determine the significance of this category. 503 secondary school students were asked to list the categories affecting their attitudes in science course in an order of importance. Table 3 was formed in line with the data obtained. 
Table 3

Findings of the Survey to Determine the Degree of Importance of Categories Affecting Students' Science Attitudes ( $n=503)$

\begin{tabular}{lcccc}
\hline Categories & Mean & SD & Highest (f) & $\%$ \\
\hline Discipline (F1) & 4.23 & 1.65 & 157 & 31.2 \\
Teacher (F2) & 4.46 & 1.49 & 149 & 29.6 \\
Learning-Teaching Process (F3) & 3.75 & 1.56 & 76 & 15.1 \\
Environment-Socio-Cultural (F4) & 2.62 & 1.31 & 13 & 2.5 \\
School (F5) & 2.49 & 1.52 & 34 & 6.7 \\
Student (F6) & 3.43 & 1.65 & 76 & 15.1 \\
\hline
\end{tabular}

When Table 3 is examined, it is seen that, in a survey where the students evaluated using 6 points, the highest mean was the teacher $(\bar{x}=4.46)$ as the category most affecting their attitudes in science course. The category least affecting their attitudes in science course was school $(\bar{x}=2.49)$. On the other hand, when it is examined to what extent the mentioned categories affect the students' science attitudes (while identifying the extent of affecting, it is identified how many of 503 participating students saw the relevant category as the category most affecting their attitude in science course), it was seen that, the category of discipline has the highest level of impact on the students' science attitudes $(31.2 \%)$. This is followed by the category of teacher. The category least affecting is found to be $(2.5 \%)$ the environment-sociocultural.

In the research, first, the factors affecting secondary school students' science attitudes were identified; later, the importance degree of the categories formed by those factors for the science attitudes was determined, which is another purpose of the research. Next, the answer was sought for the question "Is there any difference among the importance degree averages of science attitude predictors by gender?" Since the data did not exhibit a normal distribution, non-parametrical Mann-Whitney $U$ test was conducted in order to determine the significance level of the average of the difference or not in this category by gender (See Table 4). 
Table 4

Results of Mann-Whitney $U$ test

\begin{tabular}{|c|c|c|c|c|c|c|c|}
\hline Categories & Group & $\mathrm{N}$ & Mean & $\begin{array}{l}\text { Order } \\
\text { mean }\end{array}$ & Order Total & $\mathrm{U}$ & $\mathrm{p}$ \\
\hline \multirow[t]{2}{*}{ Discipline (F1) } & Females & 245 & 4.26 & 253.11 & 62011.00 & \multirow[t]{2}{*}{30599.000} & \multirow[t]{2}{*}{.685} \\
\hline & Males & 255 & 4.20 & 248.00 & 63239.00 & & \\
\hline \multirow[t]{2}{*}{ Teacher (F2) } & Females & 245 & 4.53 & 253.15 & 62021.50 & \multirow{2}{*}{30588.500} & \multirow{2}{*}{.678} \\
\hline & Males & 255 & 4.40 & 247.95 & 63228.50 & & \\
\hline \multirow{2}{*}{$\begin{array}{c}\text { Learning- } \\
\text { Teaching Process } \\
\text { (F3) }\end{array}$} & Females & 245 & 3.81 & 255.00 & 62474.00 & \multirow[b]{2}{*}{30136.000} & \multirow[b]{2}{*}{.488} \\
\hline & Males & 255 & 3.70 & 246.18 & 62776.00 & & \\
\hline \multirow{2}{*}{$\begin{array}{l}\text { Environment- } \\
\text { Socio-Cultural } \\
\text { (F4) }\end{array}$} & Females & 245 & 2.60 & 249.84 & 61210.00 & \multirow[b]{2}{*}{31075.000} & \multirow[b]{2}{*}{.918} \\
\hline & Males & 255 & 2.63 & 251.14 & 64040.00 & & \\
\hline \multirow[t]{2}{*}{ School (F5) } & Females & 245 & 2.41 & 243.80 & 59731.00 & \multirow{2}{*}{29596.000} & \multirow{2}{*}{.294} \\
\hline & Males & 255 & 2.58 & 256.94 & 65519.00 & & \\
\hline \multirow[t]{2}{*}{ Student (F6) } & Females & 245 & 3.39 & 246.43 & 60375.00 & \multirow{2}{*}{30240.000} & \multirow{2}{*}{.531} \\
\hline & Males & 255 & 3.47 & 254.41 & 64875.00 & & \\
\hline
\end{tabular}

When Table 4 is examined it is seen that, according to the results of the MannWhitney U Test, which was conducted to identify whether there was a significant difference between the average of the degree of importance of category (discipline, teacher, learning-teaching process, environment-socio-cultural, school and student) that affecting the male and female students' science attitude, there was no statistically significant difference.

After having determined the importance degree of the categories formed by the factors affecting science attitudes, the answers were sought for the question "Is there any difference among the importance degree averages of science attitude predictors by grade levels?" Since the data did not exhibit a normal distribution, non-parametrical Kruskal-Wallis test was conducted in order to determine the significance level of the average of the difference or not in this category by class level (See Table 5). 
Table 5

Results of Kruskal-Wallis test

\begin{tabular}{|c|c|c|c|c|c|c|c|c|}
\hline Categories & $\begin{array}{l}\text { Class } \\
\text { level }\end{array}$ & $\mathrm{N}$ & Mean & $\begin{array}{l}\text { Order } \\
\text { mean }\end{array}$ & $\mathrm{sd}$ & $\chi^{2}$ & $\mathrm{p}$ & $\begin{array}{l}\text { Significant } \\
\text { difference }\end{array}$ \\
\hline \multirow[t]{5}{*}{ Discipline (F1) } & 5. class & 63 & 4.01 & 226.23 & \multirow[t]{5}{*}{3} & \multirow[t]{5}{*}{8.054} & \multirow[t]{5}{*}{.045} & $5-6(\mathrm{p}=.032)$ \\
\hline & 6. class & 184 & 4.47 & 270.15 & & & & $6-7(p=.014)$ \\
\hline & 7. class & 139 & 4.02 & 231.34 & & & & \\
\hline & 8. class & 112 & 4.25 & 251.20 & & & & \\
\hline & Total & 498 & & & & & & \\
\hline \multirow[t]{5}{*}{ Teacher (F2) } & 5. class & 63 & 4.80 & 292.98 & \multirow{5}{*}{3} & \multirow{5}{*}{12.450} & \multirow{5}{*}{.006} & \\
\hline & 6. class & 184 & 4.54 & 249.69 & & & & $5-6(p=.020)$ \\
\hline & 7. class & 139 & 4.48 & 255.67 & & & & $5-8(\mathrm{p}=.002)$ \\
\hline & 8. class & 112 & 4.09 & 217.08 & & & & $7-8(\mathrm{p}=.038)$ \\
\hline & Total & 498 & & & & & & \\
\hline \multirow{5}{*}{$\begin{array}{l}\text { Learning-Teaching } \\
\text { Process (F3) }\end{array}$} & 5. class & 63 & 3.63 & 242.99 & \multirow{5}{*}{3} & \multirow{5}{*}{1.718} & \multirow{5}{*}{.633} & \\
\hline & 6. class & 184 & 3.86 & 258.89 & & & & \\
\hline & 7. class & 139 & 3.76 & 249.49 & & & & \\
\hline & 8. class & 112 & 3.66 & 237.75 & & & & \\
\hline & Total & 498 & & & & & & \\
\hline \multirow{5}{*}{$\begin{array}{c}\text { Environment- } \\
\text { Socio-Cultural (F4) }\end{array}$} & 5. class & 63 & 2.82 & 270.75 & \multirow{5}{*}{3} & \multirow{5}{*}{4.705} & \multirow{5}{*}{.195} & \\
\hline & 6. class & 184 & 2.47 & 233.04 & & & & \\
\hline & 7. class & 139 & 2.64 & 253.35 & & & & \\
\hline & 8. class & 112 & 2.73 & 259.82 & & & & \\
\hline & Total & 498 & & & & & & \\
\hline \multirow[t]{5}{*}{ School (F5) } & 5. class & 63 & 2.36 & 245.77 & \multirow{5}{*}{3} & \multirow{5}{*}{6.076} & \multirow{5}{*}{.108} & \\
\hline & 6. class & 184 & 2.34 & 236.89 & & & & \\
\hline & 7. class & 139 & 2.76 & 273.76 & & & & \\
\hline & 8. class & 112 & 2.44 & 242.21 & & & & \\
\hline & Total & 498 & & & & & & \\
\hline \multirow[t]{5}{*}{ Student (F6) } & 5. class & 63 & 3.31 & 240.09 & \multirow{5}{*}{3} & \multirow{5}{*}{7.525} & \multirow{5}{*}{.057} & \\
\hline & 6. class & 184 & 3.33 & 241.38 & & & & \\
\hline & 7. class & 139 & 3.31 & 238.49 & & & & \\
\hline & 8. class & 112 & 3.81 & 281.79 & & & & \\
\hline & Total & 498 & & & & & & \\
\hline
\end{tabular}


When Table 5 is examined it is seen that, while there was a significant difference between the average of the degree of importance of discipline and teacher category according to grade level, there was no statistically significant difference between the average of the degree of importance of learning-teaching process, environment-socio-cultural, school and student category according to grade level. While the Kruskal-Wallis Test put forth whether there was a significant difference between the compared means, it does not give information on the size of this difference. Since the Kruskal-Wallis Test does not include multiple comparisons option, a comparison was made with the Mann-Whitney U Test for the possible couples of all class levels in order to identify whether there was a significant difference between any class levels.

When Table 5 is examined, according to average of the degree of importance of discipline category, between the $5^{\text {th }}$ and $6^{\text {th }}$ classes and, the $6^{\text {th }}$ and $7^{\text {th }}$ classes and there was a significant difference in favor of the $6^{\text {th }}$ classes. On the other hand, according to average of the degree of importance of teacher category, between the $5^{\text {th }}$ and $6^{\text {th }}$ classes there was a significant difference in favor of the $5^{\text {th }}$ classes. Besides, according to average of the degree of importance of teacher category, between the $8^{\text {th }}$ classes and $5^{\text {th }}$ classes, $6^{\text {th }}$ classes and $7^{\text {th }}$ classes there was a significant difference in against of the $8^{\text {th }}$ classes.

\section{Discussion and Conclusions}

Factors affect the secondary school students' science attitudes are determined in accordance with students' opinions. Discipline, Teacher, Environment-Socio-Cultural, Learning-Teaching Process, Student and School were found as categories affecting the students' science attitude. George (2000) states that students' science attitudes are affected by their parents, their peer groups, schools, and other social factors. In their literature review, Osborne et al. (2003) classify the factors affecting the students' science attitudes as; gender, personal characteristics, teacher, curriculum change, and the difficulty to perceive science.

According to the results of the study, teacher is the most important category affecting the students' science attitudes. In their study, Sen and Koca-Ozgun (2005) state that the level of understanding the course and teacher are the leading factors for the students to develop a positive attitude towards and the science course. Altinok (2004) found that students' perception of the teacher's attitude towards the science education had an impact on students' science attitudes and their motivation for success. Morell and Lederman, (1998) and Palmer (2001) state that the teachers' science attitudes and science teaching affect the students' science attitudes. If the teachers do not like the course and if they reflect this emotion to their students, it can create negativity in students, as well. In addition, the teachers that have a negative attitude towards science education can keep the lecture time short during the course (Palmer, 2001), and thus they can negatively affect the students' science attitudes and their success.

In this study, there was no statistically significant difference between the average of the degree of importance of category (discipline, teacher, learning-teaching 
process, environment-socio-cultural, school and student) that affecting the male and female students' science attitudes. On the other hand, there was a significant difference between the average of the degree of importance of discipline and teacher category according to grade level. According to average of the degree of importance of discipline category, between the $5^{\text {th }}$ and $6^{\text {th }}$ classes and, the $6^{\text {th }}$ and $7^{\text {th }}$ classes and there was a significant difference in favor of the $6^{\text {th }}$ classes. On the other hand, according to average of the degree of importance of teacher category, between the $5^{\text {th }}$ and $6^{\text {th }}$ classes there was a significant difference in favor of the $5^{\text {th }}$ classes. Besides, according to average of the degree of importance of teacher category, between the $8^{\text {th }}$ classes and $5^{\text {th }}$ classes, $6^{\text {th }}$ classes and $7^{\text {th }}$ classes there was a significant difference in against of the $8^{\text {th }}$ classes. The status of the teacher becomes negligible when class level increases. There were no studies in the literature which show that the status of the teacher becomes negligible when class level increases. Similarly Kozcu-Cakir, Senler and Gocmen-Taskin (2007) stated that socio-economic status of students' families affect attitudes toward science course. And, Osborne, Simon and Collins (2003) have determined that course teachers, the influence of families, the classroom environment and science achievement affected the attitude towards science course.

\section{Implications}

Since the student opinions on the factors affecting secondary school students' science attitudes are the prominent element in the research results, it is necessary to increase the academic counseling activities on the subject. In the light of the fact that the category of teacher, which is the most important predictors of secondary school students' science attitudes, lost importance from the fifth-grade students to the eighthgrade students, it is necessary to give weight to the elements which will enable science teachers to play an efficient role in the next grade levels. On the other hand, regarding the category of course, which are important predictors of secondary school students' science attitudes, the science course needs to be redesigned in terms of being attractive, entertaining, supportive of choice of profession, and the duration of the course.

The predictors of science attitudes were identified in accordance only with the opinions of secondary school students in the research. Limited number of students was asked for opinions at this point. It is possible to scale of the predictors of secondary school students' science attitudes is improved with the data to be obtained from groups of broad participation. Furthermore, the predictors of high school and university students' science attitudes can be identified, too, and comparisons can be made between science attitudes by students' educational levels. Similarly, scales can be developed under the name of predictors of high school and university students' science attitudes. The developed scales can be used for determining the effect rate of factors affecting students' science attitudes. 


\section{Ortaokul Öğrencilerinin Fen Derslerine Karşı Tutumlarının Belirleyicileri}

\author{
Cemal TOSUN*
}

Makale Gönderme Tarihi: 08 Nisan 2015

\author{
Murat GENÇ**
}

Makale Kabul Tarihi: 24 Haziran 2016

ÖZ: Bu çalışmanın amacı ortaokul öğrencilerinin fen tutumlarını etkileyen faktörleri belirleyip, bu faktörlerden oluşan kategorilerin önemlilik derecesini tespit etmektir. Bu araştırmada nicel araştırma türlerinden deneysel olmayan araştırma desenlerinden tarama araştırma yöntemi kullanılmıştır. Araştırmanın örneklemini 2014-15 eğitim-öğretim yılında Bartın ve Düzce illerindeki 4 farklı ortaokulda öğrenim görmekte olan 503 öğrenci oluşturmaktadır. Veriler "Fen Tutumlarını Etkileyen Faktörler Anketi" ve "Fen Tutumlarını Etkileyen Kategorilerin Önemlilik Derecesini Belirleme Anketi" ile toplanmıştır. Nitel veriler içerik analizine tabi tutulmuştur. Nicel verilerin analizinde betimsel analizden faydalanarak ortalama ve standart sapma değerleri hesaplanmıştır. Araştırma sonuçlarına göre öğrencilerin fen bilimleri dersine karşı tutumlarını etkileyen en önemli kategorilerin başında öğretmen kategorisi geldiği belirlenmiştir.

Anahtar Kelimeler: Fen tutumlarının belirleyicileri, fen tutumu, ortaokul öğrencileri.

\section{Uzun Özet}

Tutum herhangi bir bireye, yere, olaya ya da fikre karşı olumlu ya da olumsuz tepki verme eğilimi olarak tanımlanabilir (Simpson, Koballa, Oliver \& Crawley, 1994). Tutumların olumlu ya da olumsuz olması öğrenme sürecini etkiler. Ayrıca, öğrencilerin gelecek yaşantılarına yön vermesine yardımcı olur (Seferoglu, 2004). Hendrickson (1997)'ye göre ise tutum, öğrenci başarısını tahmin etmede kullanılabilecek en iyi kestiricidir.

Araştırmanın Amacı: Öğrencilerin fen tutumlarını etkileyen birçok faktör olabilir fakat bunlardan hangilerinin daha önemli olduğu önem arz etmektedir. Bu çalı̧̧manın amacı, öğrencilerin fen tutumlarını etkileyen faktörleri farklı sınıf düzeyindeki ortaokul öğrencilerinin algılarına dayalı olarak belirlemek ve bu faktörlerden oluşan kategorilerin önemlilik derecelerini tespit etmektir.

Yöntem: $\mathrm{Bu}$ araştırmada nicel araştırma türlerinden deneysel olmayan araştırma desenlerinden tarama araştırma yöntemi (Fraenkel \& Wallen 2009, s.12) kullanılmıştır. Ortaokul ögrencilerinin, fen tutumlarını etkileyen faktörleri ve bu faktörlerden de hangilerinin daha önemli olduğunu belirlemek amacıyla bu konudaki görüşlerine başvurulmuştur. Araştırmanın bu aşamasına Bartın ve Düzce illerindeki farklı sınıf düzeyindeki toplam 126 ortaokul öğrencisi katılmıştır. Bu öğrencilerden 27'si beşinci sinıf, $45^{\prime} i$ altıncı sinıf, $25^{\prime} i$ yedinci sunıf ve 29 'u ise sekizinci smıf öğrencisidir. Fen tutumlarının belirleyicileri tespit edildikten sonra bu faktörlerin oluşturduğu

\footnotetext{
* Doç. Dr., Bartın Üniversitesi, Bartın, Türkiye, ctosun@bartin.edu.tr

** Sorumlu Yazar: Doç. Dr., Düzce Üniversitesi, Düzce, Türkiye, muratgenc77@gmail.com
} 
kategorilerin önemlilik derecesini belirlemek için Bartın ve Düzce illerindeki 4 farklı okuldaki 503 öğrencinin görüşlerine başvurulmuştur. Nitel veriler içerik analizine tabi tutulmuştur. İçerik analizinde, toplanan verileri açıklayabilecek yeni kavram ve temalara ulaşılır (Yıldırım \& Şimşek, 2006; s. 228). Nicel verilere ise betimsel analiz yapılarak ortalama ve standart sapma değerleri hesaplanmıştır. Ayrıca verilerin normal dağılım göstermemesinden dolayı non-parametrik testlerden Mann-Whitney U testinden ve Kruskal Wallis testinden de faydalanılmıştır.

\section{Veri Toplama Araçları}

Fen Tutumlarını Etkileyen Faktörler Anketi. Fen Tutumlarını Etkileyen Faktörler Anketi adında bir anket kullanılarak ortaokul öğrencilerinin fen tutumları üzerine etki eden faktörler hakkındaki görüşlerinin belirlenmesi amaçlanmıştır. $\mathrm{Bu}$ anket ile öğrencilerden gruplar halinde tartıştıktan sonra fen tutumlarına etki eden en önemli 10 (on) faktörü önem sırasına göre sıralamaları istenmiştir. Araştırmanın bu aşamasına Bartın ve Düzce illerindeki farklı sınıf düzeyindeki toplam 126 ortaokul öğrencisi katılmıştır. Anketin geçerlik çalışması için fen eğitimi alanında çalışan iki uzmanın görüşleri alınmıştır. Bu çalışmadan elde edilen veriler ham veri kodları olarak ele alınıp içerik analizine tabi tutulmuştur. Bu kodlardan Öğrenme-Öğretme Süreci, Öğretmen, Çevre-Sosyo-Kültürel, Ders, Öğrenci ve Okul başlıkları halinde kategoriler elde edilmiştir. Ayrıca, her bir koda ait frekans değerleri çıkarılarak değerlendirmeler yapılmıştır.

Fen Tutumlarını Etkileyen Kategorilerin Önemlilik Derecesini Belirleme Anketi. Ortaokul öğrencilerinin fen derslerine karşı tutumlarını etkileyen faktörler belirlendikten sonra bu faktörlerin oluşturduğu kategorilerin önemlilik derecesini belirlemek için Fen Tutumlarını Etkileyen Kategorilerin Önemlilik Derecesini Belirleme Anketinden faydalanılmıştır. $\mathrm{Bu}$ anket de ortaokul öğrencilerinin fen derslerine karşı tutumlarını etkileyen altı kategori (öğrenme-öğretme süreci, öğretmen, çevre-sosyo-kültürel, ders, öğrenci ve okul) yer almaktadır. 503 öğrenci tarafından fen tutumlarını etkileyen faktörlerin oluşturduğu kategorilerin önemlilik derecesini en az önemsedikleri kategori için 1 (bir), en çok önemsedikleri kategori için 6 (altı) sınırlarında değerlendirmeleri istenmiştir.

Sonuç ve Tartışma: Araştırma sonuçlarına göre öğrencilerin fen bilimleri dersine karşı tutumlarını etkileyen en önemli faktörlerin başında öğretmen faktörü geldiği belirlenmiştir. Şen ve Koca-Özgün (2005) tarafından yapılan çalışmada öğrencilerin fen derslerine ilişkin olumlu tutum geliştirme nedenlerinin başında dersin anlaşılma durumu ve öğretmen etkeni olduğu ifade edilmektedir. Altınok (2004) tarafindan ise öğretmenin fen öğretimine yönelik tutumunun, öğrenci tarafından algılanması durumuna göre, öğrencilerin fen bilimleri dersine yönelik tutumları ve başarıya karşı motive olma durumlarının etkilendiği tespit edilmiştir. Morell ve Lederman (1998) ve Palmer (2001) öğretmenlerin fen bilimleri dersine ve fen bilimleri öğretimine yönelik tutumlarının öğrencilerin fen bilimlerine yönelik tutumlarını etkilediğini ifade etmektedirler. 
Öğretmenlerin bu dersten hoşlanmamaları ve bu duygularını öğrencilere yansıtmaları durumu da öğrenciler de olumsuzluğa neden olabilir. Ayrıca, fen öğretimine yönelik olumsuz tutuma sahip öğretmenler ders içinde öğretime ayırdıkları süreyi kısa tutarak (Palmer, 2001) öğrencilerin fen derslerine ilişkin tutumları ve başarılarını olumsuz etkileyebilirler.

$\mathrm{Bu}$ çalışmada öğrencilerin fen derslerine karşı tutumlarını etkileyen kategorilerin (ders, öğretmen, öğrenme-öğretme süreci, çevre-sosyo-kültürel, okul ve öğrenci) önemlilik derecelerinin ortalamaları arasında cinsiyete göre kızlar ve erkekler arasında istatistiksel olarak anlamlı bir farklılık görülmemiştir. Diğer taraftan öğrencilerin fen derslerine karşı tutumlarını etkileyen kategorilerden ders ve öğretmen kategorilerinin önemlilik derecelerinin ortalamaları arasında sınıf düzeyine göre istatistiksel olarak anlamlı farklılıklar tespit edilmiştir. Bu farklılı̆̆ın ders kategorisinde 5. sinıflar ile 6. sinıflar arasında ve 6. sınıflar ile 7. sinıflar arasında olduğu görülmektedir. Öğretmen kategorisinde ise 5. siniflar ile 6. siniflar arasinda ve 5. 6. ve 7. sinıflar ile 8. sinfflar arasında olduğu belirlenmiştir. 5. sinıflardan 8. sinıflara doğru sınıf düzeyi artıkça öğretmen kategorisinin önem derecesinin ortalamasının düştüğü belirlenmiştir. $\mathrm{Bu}$ durum ortaokul öğrencilerinin fen tutumlarının en önemli belirleyicisi olarak ifade ettikleri öğretmen kategorisinin sınıf düzeyi ilerledikçe önemsenme durumunun azaldığını göstermektedir. Alan yazın çalışmalarında ortaokul öğrencilerinin fen tutumlarının belirleyicilerinden öğretmen kategorisinin sınıf düzeyi ilerledikçe önemsenme durumunun azaldığı/arttı̆̆ ile ilgili herhangi bir çalışmaya rastlanmamıştır. Kozcu-Çakır, Şenler ve Göçmen-Taşkın (2007) ailenin sosyo-ekonomik durumunun öğrencilerin fen tutumunu etkilediğini ifade etmektedirler. Ayrıca Osborne, Simon ve Collins (2003) tarafindan son yirmi yılda fene yönelik tutum ve uygulamalara ilişsin alanyazını incelemeleriyle ilgili çalışmalarının sonucunda fene yönelik tutumun; dersin öğretmeni, akranların ve ailelerin etkisi, sınıf ortamı ve fende başarı gibi faktörlerden etkilendiğini belirlemişlerdir. 


\section{References}

Altinok, H. \& Acikgoz, K.U. (2006). İşbirlikli ve bireysel kavram haritalamanın fen bilgisi dersine yönelik tutum üzerindeki etkileri [Effects of cooperative and individual concept mapping on attitudes toward science]. H.U. Journal of Education. 30, 21-29.

Altinok, H. (2004). Öğretmenlerin fen öğretimine yönelik tutumlarına ilişkin öğrenci algıları ve öğrencilerin fen bilgisi dersine yönelik tutum ve güdüleri [Teacher candidates' evaluation of their teaching competencies]. H.U. Journal of Education, $26,1-8$.

Baykul, Y. (1990). Illkokul beşinci sınıftan lise ve dengi okulların son sınıflarına kadar matematik ve fen derslerine karşı tutumda görülen değişmeler ve öğrenci seçme sınavındaki başarı ile ilişkili olduğu düşünülen bazı faktörler. Ankara: ÖSYM Yayınları.

Bloom, B. (1979). Insan nitelikleri ve okulda ögrenme. (Çev. D. A. Özçelik). Ankara: Milli Eğitim Basımevi.

Bloom, J. W. (1989). Pre-service elementary teachers' conceptions of science: science, theories and evolution. International Journal of Science Education, 1, 401-415.

Cho, H., Chung-Ang., Kim, J., \& Choi, D. H. (2003). Early childhood teachers' attitudes toward science teaching: A scale validation study. Educational Research Quarterly, 27(2), 33-42.

Dawson, C. (2000). Upper primary boys' and girls' interest in science: have they changed since 1980? International Journal of Science Education, 22(6), 557-570.

Fraenkel, J. R., \& Wallen, N. E. (2009). How to design and evaluate research in education ( $7^{\text {th }}$ ed.). McGraw, Boston: Hill Higher Education.

Fraenkel, J.R., Wallen, N.E. \& Hyun, H.H. (2012). How to design and evaluate research in education ( $8^{\text {th }}$ ed.). New York: McGraw Hill Companies.

Franz, J. R. \& Enochs, L. G. (1982). Elementary school science: State certification requirment in science and their implications. Science Education, 66, 287-292.

George, R. (2000). Measuring change in students' attitudes towards science over time: An application of talent variable growth modeling. Journal of Science Education and Technology, 9, 213-225.

Hendrickson, A. B., (1997). Predicting student success with the learning and study strategies 14. inventory (LASSI) (Unpublished Master's Thesis). Iowa State University, USA.

Kind, P., James, K. \& Barmby, P. (2007). Developing attitudes towards science measures. International Journal of Science Education, 29(7), 871-893.

Koballa, T. R., Jr., \& Crawley, F. E. (1985). The influence of attitude on science teaching and learning, School Science and Teaching, 20(4), 222-232.

Kozcu-Cakir, N., Senler, B. \& Gocmen-Taskin, B. (2007). İlköğretim II. kademe öğrencilerinin fen bilgisi dersine yönelik tutumlarının belirlenmesi [Determining 
the attitudes towards science course of second grade students in primary school], Türk Ĕ̈itim Bilimleri Dergisi, 5(4), 637-655.

McDewitt, T. M., Heikkinen, H. W., Alcorn, J. K., Ambrosio, A. L. \& Gardner, A. (1993). Evalution of the preparation of teachers in science and mathematics: Assessment of pre-service teachers' attitudes and beliefs. Science Education, 77(6), 593-610.

McMillan, J. H., \& Schumacher, S. (2006). Research in education: Evidence-based inquiry. New York. Pearson Education, Inc.

Morell, P. D. \& Lederman N. G. (1998). Students attitudes towards school and classroom science. School Science and Mathematics, 98, (2).

Osborne, J., Simon, S. \& Collins, S. (2003). Attitudes towards science: a review of the literature and its implications. International Journal of Science Education, 25(9) 1049-1079.

Palmer, D.H. (2001). Factors contributing to attitude exchange among pre-service elementary teachers. Science Education, 86, 122-138.

Pell, T. \& Jarvis, T. (2001). Developing attitude to science scales for use with children of ages from 5 to 11. International Journal of Science Education, 23(8) 847-862.

Pintrich, P. R. \& Schunk, D. H. (1996). Motivation in education: Theory, research, and 15. application. Englewood Cliffs, NJ: Prentice-Hall Inc.

Reid, N. \& Skryabina, E.A. (2002). Attitudes towards physics. Research in Science and Technological Education, 20(1), 67-81.

Richardson, V. (1996). The role of attitudes and beliefs in learning to teach. In J. Kula (Ed.), Handbook of research on teacher education (pp. 459-484). New York: Macmillan.

Seferoglu, S.S. (2004). Öğretmen adaylarının öğretmenliğe yönelik tutumları (s.413425), XII. Ulusal Eğitim Bilimleri Kongresi Bildirileri, Ankara.

Sen, A.I. \& Koca-Ozgun, S.A. (2005). Ortaöğretim öğrencilerinin matematik ve fen derslerine yönelik olan olumlu tutumları ve nedenleri. Eğitim Araştırmaları, 18, 186-201.

Simpson, R. D., Koballa Jr, T.R., Oliver, J. S. \& Crawley, F. E., (1994). Research on affective dimension of science learning. In D.L. Gabel (Ed), Handbook of research in science teaching and learning. National Science Teacher Association. NY: Macmillan Publishing Company.

Stefanich, G. P. \& Kelsey, K. W. (1989). Improving science attitudes of pre-service elementary teachers. Science Education, 73, 187-194.

Tosun, C. \& Genc, M., (2015). Adaptation of science attitude scale developed for primary school students to Turkish: Validity and reliability studies. Elementary Education Online, 14(3), 946-960, http://dx.doi.org/10.17051/io.2015.08787

Tosun, C., Ilhan, N., Tatar, E., Tuysuz, C., \& Karakuyu, Y. (2015). Ortaokul, lise ve üniversite öğrencilerinin fen başarısı belirleyicileri [Middle, High School and 
University Students' Predictors of Science Achievement]. Mehmet Akif Ersoy Üniversitesi Ĕ̈itim Fakültesi Dergisi, 35, 29-45.

Tilgner, P. J. (1990). Avoiding science in the elementary school, Science Education, 74(4), 421-431.

Turkmen, L. (2002). Sınıf öğretmenliği 1. sınıf öğrencilerinin fen bilimleri ve fen bilgisi öğretimine yönelik tutumları [Freshman elementary education major students' attitudes toward science and science teaching]. H.U. Journal of Education, 23, 218228.

Yesilyurt, M., Kurt, T. \& Temur, A. (2005). İlköğretim fen laboratuvarı için tutum anketi geliştirilmesi ve uygulanması. Pamukkale Üniversitesi Ĕ̌itim Fakültesi Dergisi, 17, 23-37.

Yildirim, A. \& Simsek, H. (2006). Sosyal bilimlerde nitel araştırma yöntemleri (5. Bask1). Seçkin Yayıncılık, Ankara. 


\section{Appendix-1}

Survey to Determine the Degree of Importance of Categories Affecting Students' Science Attitude

Give 1 point to

the least effective,

Give 6 points to

the most

effective to rank

the factors.

Category 1 Whether the course interesting us, entertaining course content, whether the course helps the choice of profession, duration of the course, etc.

Category 2 Teacher's approach towards us, teacher's behaviors during the class, whether we like our teacher, etc.

Category 3 Laboratory applications, different activities and applications performed by teacher in the class, materials used in the class, grade mark (evaluation) system of the course, punishment-award during the learning-teaching process, etc.

Category 4 Rules to be followed in the classroom, in-class behaviors exhibited by our friends, etc.

Category 5 Physical equipment and conditions of our school and classroom.

Category 6 Whether we pay attention to the course, repeat it, study in a programmed way, participate in the course, etc. 